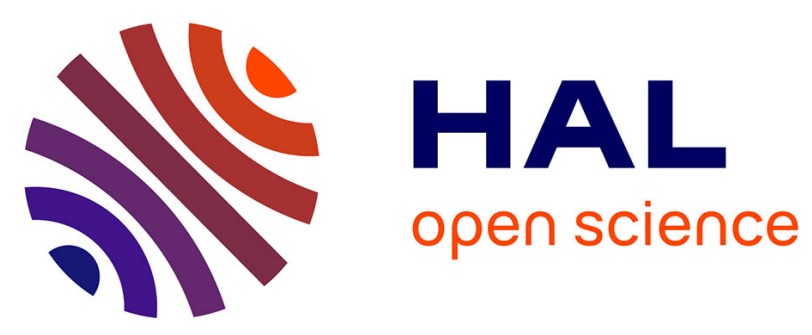

\title{
Rapid changes in plasticity across generations within an expanding cedar forest
}

\author{
Delphine Fallour-Rubio, F. Guibal, Etienne K. Klein, Michel M. Bariteau, \\ Francois Lefèvre
}

\section{- To cite this version:}

Delphine Fallour-Rubio, F. Guibal, Etienne K. Klein, Michel M. Bariteau, Francois Lefèvre. Rapid changes in plasticity across generations within an expanding cedar forest. Journal of Evolutionary Biology, 2009, 22 (3), pp.553-563. 10.1111/j.1420-9101.2008.01662.x . hal-02668572

\section{HAL Id: hal-02668572 \\ https://hal.inrae.fr/hal-02668572}

Submitted on 31 May 2020

HAL is a multi-disciplinary open access archive for the deposit and dissemination of scientific research documents, whether they are published or not. The documents may come from teaching and research institutions in France or abroad, or from public or private research centers.
L'archive ouverte pluridisciplinaire HAL, est destinée au dépôt et à la diffusion de documents scientifiques de niveau recherche, publiés ou non, émanant des établissements d'enseignement et de recherche français ou étrangers, des laboratoires publics ou privés. 


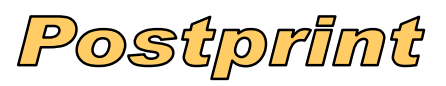

Version définitive du manuscrit publié dans / Final version of the manuscript published in : Journal of Evolutionary Biology, 2008, DOI: 10.1111/j.1420-9101.2008.01662.x

1 harsh conditions and plasticity at population level may result from an intrinsic cost of

2 phenotypic plasticity (Relyea, 2002), or from a selection for higher responsiveness in

3 favourable environments. The first hypothesis would also result in a negative correlation

4 between the response to stressful conditions and plasticity at individual level within

5 population, which is not necessarily the case for the second hypothesis.

6

7 To assess the diversity of phenotypic plasticity at individual level and investigate its short

8 term evolution within tree populations, we conducted a retrospective micro-evolution study

9 within an introduced population that experienced continuous environmental changes and

10 presents an interesting demographic structure in semi-discrete generations. We studied the

11 variation of phenotypic plasticity under the reaction norm approach (Via et al., 1995),

12 assuming a linear model of the phenotypic response in terms of annual radial growth to a

13 continuous environmental parameter, summer rainfall. Using increment cores we

14 retrospectively obtained numerous (up to 90) observations for each individual in contrasted

15 environmental conditions, leading to individual measures of plasticity. We also estimated the

16 covariance between the height and slope of linear reaction norms at individual level.

18 Transplanted forests from the 19th and 20th century represent a unique experimental 19 opportunity to perform micro-evolution studies in trees through retrospective approaches 20 (Zheng \& Ennos, 1999). Indeed, populations that were transplanted out of their natural 21 geographical range can inform us on the impact of evolutionary forces that shape the diversity 22 after rapid environmental change: demo-genetic processes and adaptation. Cedar (Cedrus 23 atlantica Manetti) had been introduced in France from Algeria mid 19th. The Luberon cedar 24 forest is located in the South East of France, under Mediterranean climate, at $700 \mathrm{~m}$ elevation. 25 Originally planted in 1863 to stop erosion in over-grazed areas (Cointat, 1996), cedar has 26 naturally regenerated without any silvicultural management until the 1990's. The species has 


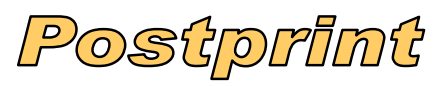

Version définitive du manuscrit publié dans / Final version of the manuscript published in : Journal of Evolutionary Biology, 2008, DOI: 10.1111/j.1420-9101.2008.01662.x

1 been transplanted from Southern to Northern latitude (from Algeria to France). However,

2 initial conditions in the transplantation site were particularly severe for Cedrus: bare and thin

3 soil, summer drought climate and strong dry northern wind (mistral). Thus, initial mortality

4 was high and the density of surviving founder trees was as low as 8 trees/ha as revealed in an

5 aerial picture dated 1939 obtained from the Institut Géographique National. These founder

6 trees produced many seeds and a closed forest was formed at the next generation, which now

7 provides much more favourable conditions for seed germination and seedling survival during

8 summer (density exceeding 50 seedlings. $\mathrm{m}^{-2}$ has been observed in a regeneration plot 8 -years

9 after germination, F. Courbet pers. comm.). Therefore, we hypothesize that a strong initial

10 selection for drought resistance has shaped the founder gene pool and, for the next

11 generations, that strong selection for competing ability occurred within dense seedling

12 patches. Three generations, or more precisely cohorts, of trees are clearly identified today,

13 including the founder trees. In a previous paper, we showed that population admixture had

14 occurred in the planting stock and that hybridisation among initial gene pools started as soon

15 as the first regeneration phase on site (Lefèvre et al., 2004). We observed no severe genetic

16 erosion, neither for neutral nor non-neutral genes, and we concluded that this population has

17 experienced intensive re-organisation of the diversity and not only genetic erosion (Fallour et

18 al., 2001; Lefèvre et al., 2004).

20 Trees are long-lived sessile organisms and their wood provides a record of the plastic

21 response to the annual change of their environment. In this study, we assessed phenotypic

22 plasticity as the response in terms of radial growth to annual climatic stochasticity through a

23 dendrochronological approach, which retrospectively provides growth data of individual trees

24 at different ages in their life. Temporal changes of environment include annual and long term

25 climatic variation, as well as the evolution of stand structure. The impact of these temporal

26 factors is partly confounded with an internal age effect. We used a global model of analysis 


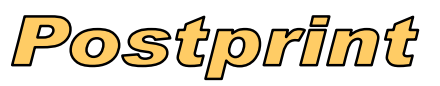

Version définitive du manuscrit publié dans / Final version of the manuscript published in : Journal of Evolutionary Biology, 2008, DOI: 10.1111/j.1420-9101.2008.01662.x

1 that accounted for these different factors and their interactions: climate, tree age and year, as a

2 surrogate for other climatic variation and evolution of stand structure. Our goals in this study

3 were to (i) estimate the variance of phenotypic plasticity at individual level within the forest,

4 (ii) investigate the changes in growth and plasticity among successive generations in various

5 environmental conditions within the forest and (iii) investigate the relationship between

6 growth performance and plasticity at individual level.

\section{Materials and methods}

10 Tree sampling

11 The cedar forest on Mount Luberon developed from 3 initial plantations with a distance of 12 about $1500 \mathrm{~m}$ between each of these areas. The population has expanded through natural 13 regeneration and currently forms a closed forest of ca 300ha. In 1995, we had sampled 197 14 trees in 3 zones of the forest, $c a .8-10$ ha each, that correspond to the initial plantation areas. 15 An aerial picture dated 1939 showed that initial mortality has been much lower and density 16 much higher in zone \#3 compared to zones \#1 and \#2. Soils conditions are homogeneous on a 17 large scale throughout the forest (calcareous lapiaz), but soil depth varies locally at very small 18 scale (Fallour, 1998).

20 Sampled trees belonged to 3 different age classes as described in a previous publication 21 (Lefèvre et al., 2004): G0, the surviving founder trees issued from seeds collected in the 22 natural range, G1, the first generation that appeared on site from intercrossing among G0 trees 23 and G2, the second generation that appeared when G1 trees became fertile (G0 still there). 24 Sampled trees were individually mapped within each zone: successive generations slightly 25 differ in their spatial distribution with a clearly clustered pattern within generation and 26 repulsion between generations (Fig.1). 


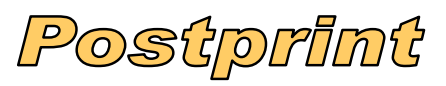

Version définitive du manuscrit publié dans / Final version of the manuscript

published in : Journal of Evolutionary Biology, 2008, DOI: 10.1111/j.1420-9101.2008.01662.x

1 The first period showed a slightly higher variance among years but this was not significant

2 (Levene's homogeneity of variance test, $F_{2,88}=2.82, \mathrm{P}_{\text {value }}=0.064$ ).

\section{Statistical analysis}

5 For each tree, we computed annual radial growth increment (RGI) as the mean of annual ring-

6 width by averaging the 3 core chronologies. Phenotypic plasticity was defined as the linear

7 response (slope) in RGI to summer rainfall. A linear mixed effect model was used where RGI

8 varied among zones, generations and years, depending on the age of trees and summer rainfall

9 (MJJA) as covariates. A random effect of individuals within each zone and generation was

10 also included. The variation of plasticity among zones and generations, but also among

11 individuals within each generation, was directly investigated within the model by the use of

12 interaction effects implying MJJA. Thus, the terms included in the global model were as

13 follows:

14 - Zone ( $\alpha$, fixed): large scale spatial heterogeneity of environmental condition (topography

15 and stand dynamics) in different parts of the forest;

16 - Generation ( $\beta$, fixed): a genetic effect partly confounded with a micro-environmental

17 effect because of different spatial distributions of generations within each zone;

18 - Zone $x$ Generation ( $\alpha \beta$, fixed): the interaction among previous effects;

19 - Age (covariate): we assumed a quadratic effect of age to account for the juvenile and senile

20 phases of RGI, which was not corrected for tree diameter prior to the analysis;

$21-M J J A$ (covariate): a linear effect of summer rainfall on radial growth (it is sufficient to 22 consider a linear rather than a quadratic relationship because water availability is a limiting 23 factor for growth in the Mediterranean);

$24-\operatorname{Year}(\delta$, fixed): a categorical variable beside the climatic covariate MJJA to account for 25 other annual climatic variability and all other temporal variations, in particular the 26 evolution in stand structure (tree density); 


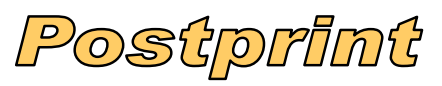

Version définitive du manuscrit publié dans / Final version of the manuscript

published in : Journal of Evolutionary Biology, 2008, DOI: 10.1111/j.1420-9101.2008.01662.x

1 - MJJA $x$ Zone and MJJA $x$ Generation (fixed): interaction terms accounting for the

2 difference in plasticity among zones and among generations;

3 - MJJA x Generation $x$ Zone (fixed): variation among zones of the generational differences

$4 \quad$ in plasticity;

5 - MJJA $x$ Age and MJJA $x A g e^{2}$ (fixed): variation of the response to climate with age,

6 constant among zones and generations;

7 - Individual (random): variance of growth among individual trees within each zone and

8 generation; differences among generations of inter-individual variances were allowed;

$9-M J J A x$ Individual (random): variance of phenotypic plasticity among individual trees

10 within each zone and generation; differences among generations of inter-individual

11 variances were allowed;

12 - a covariance between the Individual effect and the MJJA $x$ Individual effect was estimated

13 within each generation.

15 We also investigated the presence of a spatial structure in the Individual effects, and whether

16 the variance among individuals and the spatial structure varied among generations (generation

17 as a GROUP of the RANDOM effect in SAS).

19 Finally, we included a temporal covariance structure in the residuals to account for the intra-

20 individual correlations among observations. We used a first-order autoregressive model,

$21 \mathrm{AR}(1)$, where the correlation between two residuals of a given individuals decreases with the

22 lag $t$ between these observation as a function $\operatorname{corr}(\mathrm{t})=\rho^{\mathrm{t}}$. The correlation between two

23 residuals of two different individuals equals zero. The auto-correlation parameter $\rho$ was

24 estimated jointly with all other parameters. A positive value of $\rho$. may be due to an "after-

25 effect" of any single event over several consecutive years of growth. A negative auto-

26 correlation $\rho$ is expected when high and low growth alternate in successive years. 


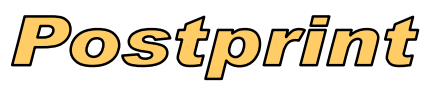

Version définitive du manuscrit publié dans / Final version of the manuscript published in : Journal of Evolutionary Biology, 2008, DOI: 10.1111/j.1420-9101.2008.01662.x

1 and $A g e^{2}$ because this would be totally included within the Year effect in a type III test. In

2 order to achieve a robust test of fixed effects, we used the Satterthwaite correction to compute

3 the degrees of freedom (Littell et al., 2006). Note that tests of fixed effects (such as

4 Generation) refer to the difference among treatments for null values of the covariates and,

5 therefore, to stressful conditions where $M J J A=0$.

6

7 Since trees from different generations both differed in age at a given year and experienced

8 different stand structure or different climatic conditions at a given age, mean values per

9 generation were not directly comparable due to confounding effects. Therefore, for each

10 generation within each zone, we computed means of growth and plasticity adjusted for Age, at

11 ages ranging from 10 to 100 years, and for Year, restricting to 1960-1994 that represents a

12 period of stable stand structure shared by all trees from the three generations. We first

13 obtained predicted growth values for each year and each age during this period using the

14 estimated model. Then, we computed adjusted means of growth under stressful climate and

15 plasticity respectively by the intercept and the slope of the regressions of predicted growth on

16 corresponding values of summer rainfall; we then used these two parameters to compute

17 adjusted means of growth in favourable conditions (i.e. value of $M J J A=350$ ). These adjusted

18 means were comparable among generations.

\section{Results}

\section{Variation patterns for radial growth increment (RGI)}

23 Although many observations contributed to the analysis (12901), the global model accounted 24 for a fair amount $\mathrm{R}^{2}=54 \%$ of total variation. 


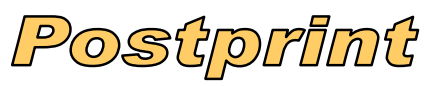

Version définitive du manuscrit publié dans / Final version of the manuscript published in : Journal of Evolutionary Biology, 2008, DOI: 10.1111/j.1420-9101.2008.01662.x

1 Differences in RGI among zones was highly significant $\left(\mathrm{P}_{\text {value }}<0.0001\right.$, Table 1$)$. In particular

2 zone \#3 had a lower growth than zones \#1 and \#2. Globally, over the whole study period, we

3 detected no difference among generations, neither for the whole forest nor within each zone

4 (Generation and Zone $x$ Generation effects non significant, Table 1). However, the

5 comparison of growth potential among generations deserves more detailed analysis because,

6 over the whole study period, they experienced different environmental changes at different 7 ages.

9 Globally, there was a highly significant response of RGI to summer rainfall MJJA $10\left(\mathrm{P}_{\text {value }}<0.0001\right.$, Table 1$)$ that confirms the relevance of this climatic variable as a determinant 11 for growth. Besides, the Year effect was highly significant $\left(\mathrm{P}_{\text {value }}<0.0001\right.$, Table 1$)$, which 12 reveals another prevailing environmental factor of temporal variation different from summer 13 rainfall. This temporal Year effect is largely explained by the evolution of stand structure as 14 can be seen from Fig. 2: see the much larger growth of G0 trees alone in the first years 15 compared to juvenile growth of G1 and G2 individuals, see also the decrease of growth of G0 16 and G1 individuals while G2 trees emerged during the $1960-1975$ period.

18 The quadratic effect of age on RGI was highly significant and provided a parabolic shape of 19 radial growth with a maximum at ages 67, 61 and 58 for summer rainfall MJJA of 0, 200 and $20350 \mathrm{~mm}$ respectively.

22 We estimated the Year and quadratic Age effects from the global model and used these 23 parameters to predict the RGI values that each generation would experience within each zone 24 during any of the years within the period 1960-1994 of stable stand structure and where all 25 three generations were effectively present. The same pattern was observed in all three zones: 26 the G0 generation had the lowest predicted growth in stressful climate (i.e. MJJA=0) whereas 


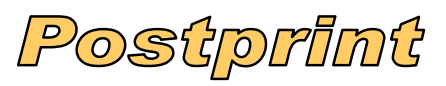

Version définitive du manuscrit publié dans / Final version of the manuscript published in : Journal of Evolutionary Biology, 2008, DOI: 10.1111/j.1420-9101.2008.01662.x

1 the $\mathrm{G} 2$ generation had the highest predicted growth in favourable conditions (i.e. MJJA=350),

2 the G1 generation was rather similar to G2 in stressful climate and to G0 in favourable

3 conditions (Fig. 3). In zone \#3, the difference between generations was larger for growth in

4 stressful conditions but smaller for growth in favourable conditions (Fig. 3)

5

6 Inter-individual variance estimates for RGI at $M J J A=0$ were not significantly different from 0

7 within any generation (Table 1). Inter-individual variance estimates for RGI at $M J J A=350$

8 were almost 20-times higher, decreasing from G0 to G1 and increasing from G1 to G2.

10 No spatial structure of individual effects could be detected. This means that close individuals

11 did not show correlated RGI and implies that the clustering of individuals of the same 12 generation (see Fig.1) should not be responsible for the detected differences in mean RGI 13 among generations.

15 Temporal autoregressive structure in the residuals was highly significant and the 16 autocorrelation parameter estimates were positive within each generation $(A R(1)=0.799$ for 17 generation $\mathrm{G} 0, \mathrm{AR}(1)=0.867$ for $\mathrm{G} 1$ and $\mathrm{AR}(1)=0.756$ for $\mathrm{G} 2$ with $\mathrm{P}_{\text {value }}<0.0001$ in all cases). 18 This temporal pattern was beyond the temporal trends included at higher level within the Year 19 and Age effects.

\section{Variation patterns for phenotypic plasticity}

22 The response to summer rainfall varied with age in a quadratic way (MJJA $\mathrm{x}$ Age and $23 M J J A \times A g e^{2}$ effects both significant, $\mathrm{P}_{\text {value }}<0.0001$, Table 1). Plasticity was maximum at 24 intermediate age, i.e. in a multiplicative effect where growth variation due to climate was 25 maximum when growth was maximum. There was a significant variation of plasticity among 26 zones (different slopes in the different zones depicted by the MJJA $x$ Zone effect, 


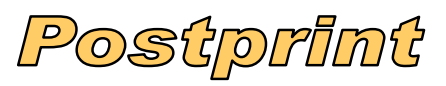

Version définitive du manuscrit publié dans / Final version of the manuscript published in : Journal of Evolutionary Biology, 2008, DOI: 10.1111/j.1420-9101.2008.01662.x

$1 \mathrm{P}_{\text {value }}<0.0001$, Table 1) and zone \#3 was characterised by lower predicted values of plasticity

2 for the 1960-1994 period (Fig. 3). Furthermore, the variation of plasticity among generations

3 was highly significant (MJJA $x$ Generation effect, tested for a value of Age $=0, \mathrm{P}_{\text {value }}<0.0001$,

4 Table 1), even greater than variation among zones. This variation among generations was

5 stable over the 3 zones of the forest (MJJA $x$ Zone $x$ Generation not significant, $\mathrm{P}_{\mathrm{value}}=0.091$,

6 Table 1). The difference between generations for predicted values of plasticity during the

7 1960-1994 period resulted from the differences for RGI both in stressful climate and

8 favourable conditions as previously mentioned. Predicted plasticity values increased from G0

9 to G2 in zone \#1 and zone \#2, mainly because of increased growth potential in favourable

10 conditions. The situation was different in zone \#3 where growth potential in stressful climate

11 increased even more between G0 and G2, which finally resulted in similar values of plasticity

12 between the two generations. The G1 generation had the lowest predicted plasticity due to a

13 higher RGI in stressful climate than G0 and a lower RGI in favourable conditions than G2

14 (Fig. 3).

16 Inter-individual variance of plasticity was highly significant within G0 and G1, and it was 17 marginally significant within G2 (Individual x MJJA variance, Table 1). The inter-individual 18 variance of plasticity slightly decreased from G0 to G1 and remained constant from G1 to G2.

19 The goodness of fit of the regression of growth on summer rainfall for each individual tree 20 varied from $\mathrm{R}^{2}=0.1 \%$ to $33 \%$ in the raw data and from $\mathrm{R}^{2}=2 \%$ to $63 \%$ when using growth 21 values predicted by the global model (Fig. 4). As expected from the Individual x MJJA 22 variance parameters, the fit was better for the younger generation G2.

24 Within each generation, the inter-individual covariance between growth (estimated in the 25 model at $M J J A=0$ ) and plasticity was significantly positive and strongly increased from G0 to 26 G2 (Table 1). 


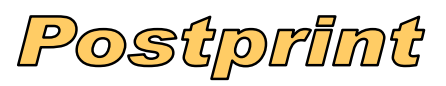

Version définitive du manuscrit publié dans / Final version of the manuscript published in : Journal of Evolutionary Biology, 2008, DOI: 10.1111/j.1420-9101.2008.01662.x

1 Within the forest, the three sampled zones significantly differed for growth and plasticity. The

2 lowest growth was found in zone \#3 although the highest survival rate of the initial plantation

3 had occurred in this area. This variation in growth performance among zones relates both to

4 ecological heterogeneity as well as differences in stand structure and stand dynamics. After

5 initial plantation in harsh conditions to which G0 trees had to survive, the environmental

6 conditions have progressively changed since the establishment of the G1 generation: an

7 organic layer has developed, a semi-closed stand structure has developed providing a shelter

8 for young seedlings during hot and dry summer, the competition from herbaceous species has

9 decreased, while the seed set and the competition among seedlings have increased. Higher

10 initial survival rate in zone \#3 resulted in higher density and higher competition in the area at

11 generation G0, thus reducing both radial growth and its response to climate (plasticity)

12 through a multiplicative effect.

14 Over the whole study period, there was no significant variation of radial growth under 15 stressful conditions, neither among generations nor among individuals within generation.

16 However, this is not direct evidence of the absence of genetic effects for growth because,

17 during the entire period of time, the different generations did not experience the same stand

18 structures at the same age. Indeed, the adjusted means of growth for the period 1960-1994

19 systematically increased from the G0 to G2 generation in each of the three zones, i.e. in three

20 different environments, both under stressful and favourable climatic conditions (MJJA=0 and

21350 respectively). Furthermore, in medium stress conditions (analysis with centred MJJA,

22 data not shown), the Generation effect on RGI significantly increased from G0 to G2 even for

23 the whole study period. Moreover, individual variance estimates in favourable conditions

$24(M J J A=350)$ were significant within each zone and each generation for the whole study

25 period and, finally, there was no spatial structure of the individual effects as would be 26 expected if micro-environmental heterogeneity were the main driver of the inter-individual 


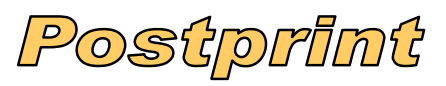

Version définitive du manuscrit publié dans / Final version of the manuscript published in : Journal of Evolutionary Biology, 2008, DOI: 10.1111/j.1420-9101.2008.01662.x

1 variance. These results strongly suggest that genetic variation exists for growth potential and

2 that it increased in two generations, although it was masked in the global analysis by major

3 environmental changes that occurred over the study period. The inter-individual variance for

4 growth decreased from G0 to G1 and then increased from G1 to G2: such evolution was

5 expected given the initial population admixture at G0 (Lefèvre et al., 2004), forming a

6 "hybrid generation" at G1, further segregating at G2.

8 Individual variance estimates for phenotypic plasticity were significant within each generation

9 over the whole study period. The absence of spatial structure among individual effects is a

10 clear indication that such variation among individuals within generations was not only due to

11 micro-environmental effects but also, at least partly, under genetic control. The existence of

12 genetic diversity for the plasticity of a trait not only has an impact on its response to selection

13 when environment changes (Pigliucci \& Murren, 2003; Crispo, 2007), but it also means that

14 plasticity itself can evolve. Previously, by using common garden experiments of controlled

15 crosses in eucalypts, Bouvet et al. (2005) had demonstrated that plasticity, defined as growth

16 response to stand density, was under genetic control and could therefore respond to selection.

18 The unbalanced design was an unavoidable challenge for such in situ study of plasticity

19 across several generations of trees: individuals from different generations did not experience

20 the same stand structure at the same age. Therefore, we assumed that each zone and each

21 generation respond similarly to age but can vary in growth and plasticity and we used type III

22 tests to avoid confounding between Age, Year and Generation effects on growth and

23 plasticity. We checked, by simulating data on the same unbalanced experimental design as

24 here (data available as supplementary material), that the type III tests would not artificially

25 lead to a significant difference of plasticity among generations when such difference does not

26 exist. For example, decreased growth and/or increased plasticity with years (that could be 


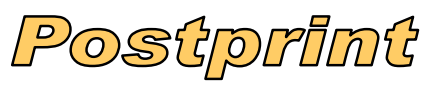

Version définitive du manuscrit publié dans / Final version of the manuscript published in : Journal of Evolutionary Biology, 2008, DOI: 10.1111/j.1420-9101.2008.01662.x

1 related to the evolution of stand structure) did not lead to confounding between Generation

2 and Year effects. The only simulation where non-existing difference of plasticity would

3 appear more frequently than 0.05 was in the case of important spatial structure of growth and

4 plasticity (confounded with spatial clustering of the generations), which was not the case here.

5 Thus, based on the assumption of constant response to age, the adjusted means for the

6 common period of stable stand structure 1960-1994 computed from the effects estimated over

7 the whole dataset could be compared between generations.

8

9 We revealed significant changes of phenotypic plasticity across generations both over the

10 whole period and the restricted period of stable stand structure. These changes did not simply

11 result from a multiplicative effect as did the difference among zones: for example, the G1

12 generation had a higher growth in dry conditions than G0 but a lower plasticity and similar

13 growth in favourable years. Three non-exclusive hypotheses could account for the variation of

14 plasticity across generations: (i) an environmental effect on the response to age inducing a

15 difference of this response among generations (that we assumed to be constant in our

16 analysis), (ii) a genetic response to various selection pressure (selection for tolerance to

17 drought stress in G0 vs selection for competing ability and higher responsiveness in G2) or

18 (iii) a genetic change due to complex genetic architecture and segregation patterns following

19 initial population admixture. The first hypothesis would represent a long-term record of

20 environmental changes within the life-span of trees, the other two hypotheses would represent

21 genetic evolution. The first two hypotheses depend on environmental conditions, and we

22 would therefore expect different generational changes among zones, wheras the third

23 hypothesis does not depend on environmental conditions and should have the same impact

24 anywhere. Indeed, in all zones we observed a decrease of plasticity from G0 to G1, followed

25 by an increase from G1 to G2, but the amount of increase from G1 to G2 varied among zones.

26 Therefore we suspect that phenotypic plasticity has genetically evolved since the original 


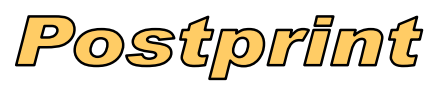

Version définitive du manuscrit publié dans / Final version of the manuscript published in : Journal of Evolutionary Biology, 2008, DOI: 10.1111/j.1420-9101.2008.01662.x

1 admixture, with or without further response to selection. Contrasting with growth, the inter-

2 individual variance of plasticity did not increase from G1 to G2 as expected from the

3 admixture scenario alone, suggesting a stabilising selection constraint in G2. This would

4 indicate different selection patterns for growth and plasticity in this forest. The environmental

5 or genetic origins of the generational changes of plasticity still need further investigation,

6 using in situ or common garden approaches.

8 The evolution of phenotypic plasticity raises the question of costs and limits of plasticity that

9 has been treated theoretically more often than empirically (Relyea, 2002; Steinger et al., 10 2003; Pigliucci, 2005). In this study, at individual level within each generation, we detected a 11 positive covariance between plasticity and tolerance to drought stress. Interestingly, despite 12 the positive covariance at individual level, we observed one case of antagonistic variation 13 across generations: in zone \#3, the G1 generation had a better growth in stressful conditions 14 but lower plasticity than G0. More generally, the G1 and G2 generations did not differ for 15 tolerance to drought stress but differed for plasticity. Therefore, the Cedrus case does not 16 support the hypothesis of intrinsic cost of plasticity, it rather shows an increased 17 responsiveness at the $\mathrm{G} 2$ generation. If selection has contributed to the change of plasticity 18 across generations, the correlated increase in growth and plasticity from G1 to G2 would 19 suggest a Baldwin effect of adaptive evolution through adaptive phenotypic plasticity rather 20 than a genetic assimilation process with increased canalization (Crispo, 2007). In the absence 21 of cost of plasticity at individual level, the balance between selection pressure for stress 22 tolerance or competing ability in different environments could explain the trade-off between 23 plasticity and stress tolerance generally observed among forest tree populations. 


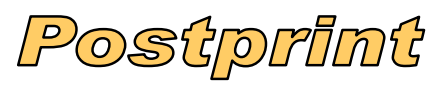

Version définitive du manuscrit publié dans / Final version of the manuscript published in : Journal of Evolutionary Biology, 2008, DOI: 10.1111/j.1420-9101.2008.01662.x

1 Acknowledgements

2 We thank F. Courbet, Ph. Dreyfus, A. Franc, C. Lavigne, O. Ronce, L. Sanchez and the

3 anonymous reviewers for their very helpful comments on earlier version of this manuscript.

4 We thank B. Jouaud and D. Vauthier for technical assistance. We greatly acknowledge the

5 Office National des Forêts and the Parc Naturel Régional du Luberon for their assistance and,

6 particularly, for helping us to find historical archives. This work was part of the project

7 'Adaptation and selection of Mediterranean Pinus and Cedrus for sustainable afforestation of

8 marginal lands' FAIR CT95-0097 financed by the Commission of the European

9 Communities DGVI.

10

\section{References}

13 Bouvet, J.M., Vigneron, P. \& Saya, A. 2005. Phenotypic plasticity of growthtrajectory and ontogenic allometry in response to density for Eucalyptus hybrid clones and families. Ann. Bot. 96: 811-821.

16 Brommer, J.E., Merila, J., Sheldon, B.C. \& Gustafsson, L. 2005. Natural selection and genetic variation for reproductive reaction norms in a wild bird population. Evolution 59: $1362-1371$.

19 Charmantier, A., McCleery, R.H., Cole, L.R., Perrins, C., Kruuk, L.E.B \& Sheldon B.C. 2008. Adaptive phenotypic plasticity in response to climate change in a wild bird population. Science 320: 800-803.

22 Chuine, I., Belmonte, J. \& Mignot, A. 2000. A modelling analysis of the genetic variation of phenology between tree populations. J. Ecol. 88: 561-570.

24 Cointat, M. 1996. Le roman du cèdre. Revue Forestière Française 48: 503-526.

25 Crispo, E. 2007. The Baldwin effect and genetic assimilation: revisiting two mechanisms of 26 evolutionary change mediated by phenotypic plasticity. Evolution 61: 2469-2479. 


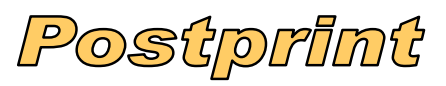

Version définitive du manuscrit publié dans / Final version of the manuscript published in : Journal of Evolutionary Biology, 2008, DOI: 10.1111/j.1420-9101.2008.01662.x

1 Daubree, J.B. \& Kremer, A. 1993. Genetic and phenological differentiation between introduced and natural populations of Quercus rubra L. Ann. Sci. Forest. 50 (suppl. 1): 271s-280s.

4 Davis, M.B. \& Shaw, R.G. 2001. Range shifts and adaptive responses to quaternary climate change. Science 292: 673-679.

6 Ducousso, A., Guyon, J.P. \& Kremer, A. 1996. Latitudinal and altitudinal variation of bud burst in western populations of sessile oak (Quercus petraea (Matt.) Liebl. Ann. Sci. Forest. 53: 775-782.

9 Duncan, R. 1989. An evaluation of errors in tree age estimates based on increment cores in kahikatea (Dacrycarpus dacrydioides). New Zealand Natural Sciences 16: 31-37.

11 Ellner, S. \& Hairston, N.G. 1994. Role of overlapping generations in maintaining genetic variation in a fluctuating environment. Am. Nat. 143: 403-417.

13 Eriksson, G., Andersson, S., Eiche, V., Ifver, J. \& Persson, A. 1980. Severity index and transfer effects on survival and volume production of Pinus sylvestris in norther Sweden. Studia Forestalia Suecica No156, 32pp .

16 Fallour, D. 1998. Evolution et structuration spatiale de la diversité du cèdre de l'Atlas sur le Petit Luberon: approches écologique, dendroécologique et génétique. $\mathrm{PhD}$ thesis, University of Aix-Marseille III, France.

19 Fallour, D., Fady, B. \& Lefèvre, F. 2001. Evidence of variation in segregation patterns within a Cedrus population. J. Hered. 92: 260-266.

21 Gillespie, J.H. \& Turelli, M. 1989. Genotype-environment interactions and the maintenance of polygenic variation. Genetics 10: 253-280.

23 Guibal, F. 1985. Dendroclimatologie du cèdre de l'Atlas dans les reboisements du Sud-Est de la France. Ecologia Mediterranea 11: 87-103.

25 Guiot J. 1986. Sur la détermination de régions climatiques quasi-homogènes. Revue de 26 Statistiques Appliquées 34: 15-34. 


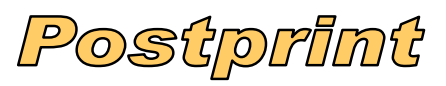

Version définitive du manuscrit publié dans / Final version of the manuscript published in : Journal of Evolutionary Biology, 2008, DOI: 10.1111/j.1420-9101.2008.01662.x

1 Higgins, S.I., Clark, J.S., Nathan, R., Hovestadt, T., Schurr, F., Fragoso, J.M.V., Aguiar, M.R., Ribbens, E. \& Lavorel, S. 2003. Forecasting plant migration rates: managing uncertainty for risk assessment. J. Ecol. 91: 341-347.

4 Kaufman, S.R. \& Smouse, P.E. 2001. Comparing indigineous and introduced populations of Melaleuca quinquenervia (Cav.) Blake: response of seedlings to water and $\mathrm{pH}$ levels. Oecologia 127: 487-494.

7 Lefèvre, F., Fady, B., Fallour-Rubio, D., Ghosn, D. \& Bariteau, M. 2004. Impact of founder population, drift and selection on the genetic diversity of a recently translocated tree population. Heredity 93: 542-550.

10 Littell, R.C., Milliken, G.A., Stroup, W.W., Wolfinger, R.D. \& Schabenberger, O. 2006. SAS for Mixed Models, Second Edition SAS Institute Inc., Cary, NC.

Matyas, C. \& Yeatman, C.W., 1992. Effect of geographical transfer on growth and survival of jack pine Pinus banksiana Lamb populations. Silvae Genet. 41: 370-376.

14 McLachlan, J.S., Clark, J.S. \& Manos, P.S. 2005. Molecular indicators of tree migration capacity under rapid climate change. Ecology 86:2088-2098.

Mikola, J. 1982. Patterns of adaptation in forest trees. Silva Fenn. 16: 141-187.

17 Miner, B.G., Sultan, S.E., Morgan, S.G., Padilla, D.K. \& Relyea, R.A. 2005. Ecological consequences of phenotypic plasticity. Trends Ecol. Evol. 12: 685-692.

19 Modrzynski, J. \& Eriksson, G. 2002. Response of Picea abies populations from elevational transects in the Polish Sudety and Carpathian mountains to simulated drought stress. Forest Ecol. Manag. 165: 105-116.

22 Nussey, D.H., Postma, E., Gienapp, P. \& Visser, M.E. 2005. Selection on heritable phenotypic plasticity in a wild bird population. Science 310: 304-306.

24 Nussey, D.H., Wilson, A.J. \& Brommer, J.E. 2007. The evolutionary ecology of individual 25 phenotypic plasticity in wild populations. J. Evol. Biol. 20: 831-844. 


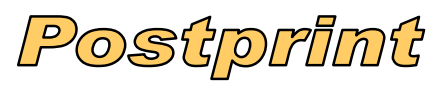

Version définitive du manuscrit publié dans / Final version of the manuscript published in : Journal of Evolutionary Biology, 2008, DOI: 10.1111/j.1420-9101.2008.01662.x

1 Pigliucci, M. 2005. Evolution of phenotypic plasticity: where are we going now? Trends Ecol. Evol. 20: 481-486.

3 Pigliucci, M. \& Murren, C.J. 2003. Perspective: genetic assimilation and a possible evolutionary paradox: can macroevolution sometimes be so fast as to pass us by? Evolution 57: 1455-1464.

6 Rehfeldt, G.E., Wykoff, W.R. \& Ying, C.C. 2001. Physiological plasticity, evolution, and impacts of a changing climate on Pinus contorta. Climatic Change 50: 355-376.

8 Rehfeldt, G.E., Tchebakova, N.M., Parfenova, Y.I., Wykoff, W.R., Kuzmina, N.A. \& Milyutin, L.I. 2002. Intraspecific responses to climate in Pinus sylvestris. Global Change Biol. 8: 912-929.

11 Relyea, RA. 2002. Cost of phenotypic plasticity. Am. Nat. 159: 272-282.

12 Savolainen, O., Bokma, F., Garcia-Gil, R., Komulainen, P. \& Repo, T. 2004. Genetic variation in cessation of growth and frost hardiness and consequences for adaptation of Pinus sylvestris to climatic change. Forest Ecol. Manag. 197: 79-89.

15 Savolainen, O., Pyhäjärvi, T. \& Knürr, T. 2007. Gene flow and local adaptation in trees. Annu. Rev. Ecol. Evol. Syst. 38: 595-619.

17 Schlichting, C.D. 1986. The evolution of phenotypic plasticity in plants. Annu. Rev. Ecol. Evol. Syst. 17: 667-693.

19 Schweingruber, F.H., Eckstein, D., Serre-Bachet, F. \& Braker, O.U. 1990. Identification, presentation and interpretation of event years and pointer years in dendrochronology. Dendrochronologia 8: 9-38.

22 Skrøppa, T. \& Kohmann, K. 1997. Adaptation to local conditions after one generation in Norway spruce. Forest Genetics 4: 171-177.

24 Stearns, S.C. 1989. The evolutionary significance of phenotypic plasticity. BioScience 39: 436-445. 


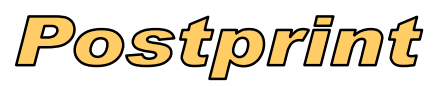

Version définitive du manuscrit publié dans / Final version of the manuscript published in : Journal of Evolutionary Biology, 2008, DOI: 10.1111/j.1420-9101.2008.01662.x

1 Table 1. ANOVA tests of fixed and random effects on radial growth increment.

2 Fixed effects $\quad$ Num DF $\quad$ Den DF $\quad F \quad P_{\text {value }}$

3

4 Zone

5 Generation

6 Zone $x$ Generation

7 Age

$8 \mathrm{Age}^{2}$

9 MJJA

10 Year

11 MJJA x Zone

12 MJJA x Generation

13 MJJA x Generation x Zone

14 MJJA x Age

15 MJJA $x \mathrm{Age}^{2}$

16

17 Random effects

18

19 Individual (at MJJA=0)

20 Individual (at MJJA=0)

21 Individual (at MJJA=0)

22 Individual at $M J J A=350$

23 Individual at $M J J A=350$

24 Individual at $M J J A=350$

25 MJJA $x$ Individual $=P P$

26 MJJA $x$ Individual $=P P$

27 MJJA $x$ Individual $=P P$

28 Cov(Individual, PP)

29 Cov(Individual, PP)

30 Cov(Individual, PP)
2

4

1

1

1

1

89

2

2

4

1

1

\begin{abstract}
146
\end{abstract}
260

107

533

1273

274

3818

122

149

87.4

270

9261
19.06

2.62

2.39

29.89

76.58

1618.02

131.62

13.09

50.59

2.07

56.65

256.60

$<0.0001$

$<0.0001$

Level

Variance/Cov

$\mathrm{P}_{\text {value }}$

$\begin{array}{lll}\text { within G0 } & 162.10 & 0.259 \\ \text { within G1 } & 0 & - \\ \text { within G2 } & 173.86 & 0.404 \\ \text { within G0 } & 3073 & <0.0001 \\ \text { within G1 } & 2587 & 0.0003 \\ \text { within G2 } & 5847 & 0.0006 \\ \text { within G0 } & 0.016 & <0.0001 \\ \text { within G1 } & 0.009 & 0.0003 \\ \text { within G2 } & 0.010 & 0.045 \\ \text { within G0 } & 1.329 & 0.051 \\ \text { within G1 } & 2.180 & 0.016 \\ \text { within G2 } & 6.329 & <0.0001\end{array}$

31

33 Fixed effects were tested following type III tests, except summer rainfall covariate (MJJA) for 34 which we used type I test to avoid complete confounding with Year effect. Variance 35 components were estimated using REML. See text for further details on the model of analysis. 
P○S\{

Version définitive du manuscrit publié dans / Final version of the manuscript published in : Journal of Evolutionary Biology, 2008, DOI: 10.1111/j.1420-9101.2008.01662.x

1 Figure 1

2
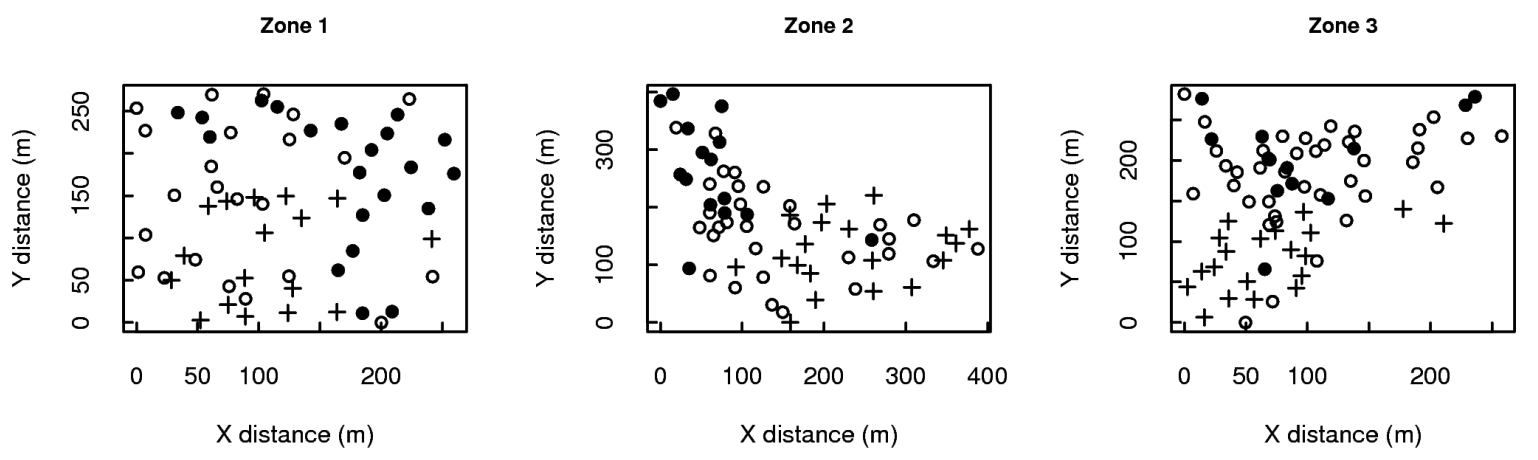


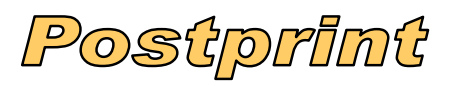

Version définitive du manuscrit publié dans / Final version of the manuscript published in : Journal of Evolutionary Biology, 2008, DOI: 10.1111/j.1420-9101.2008.01662.x

1 Figure 3

2

Zone 1
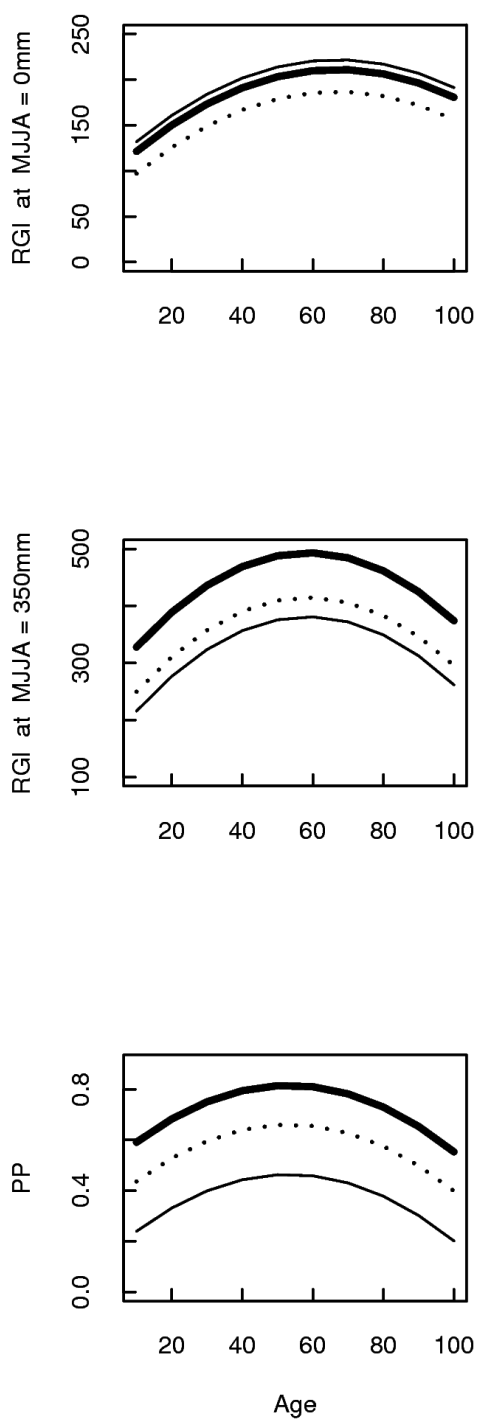

Zone 2
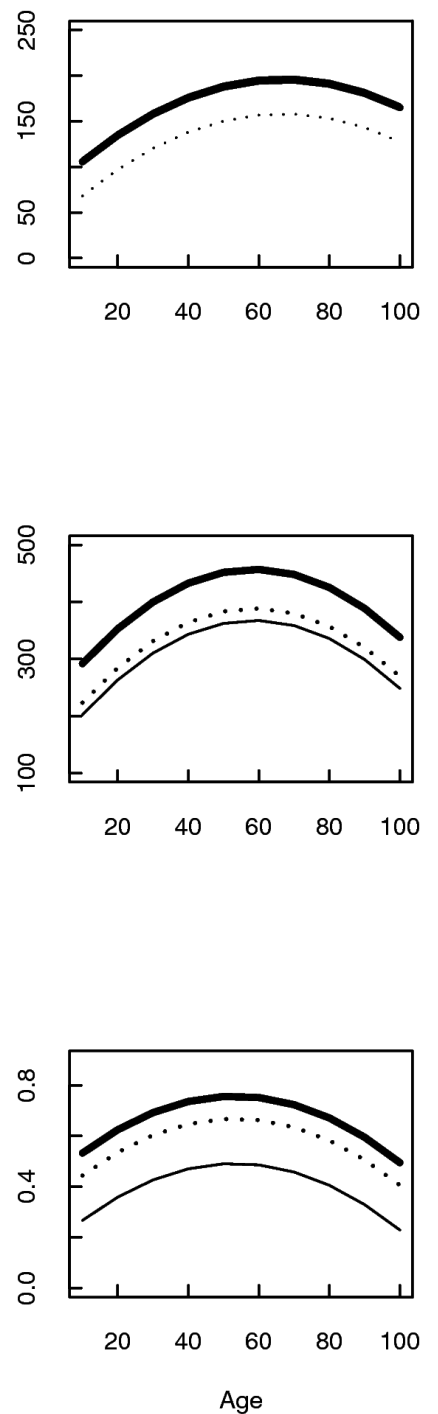

Zone 3
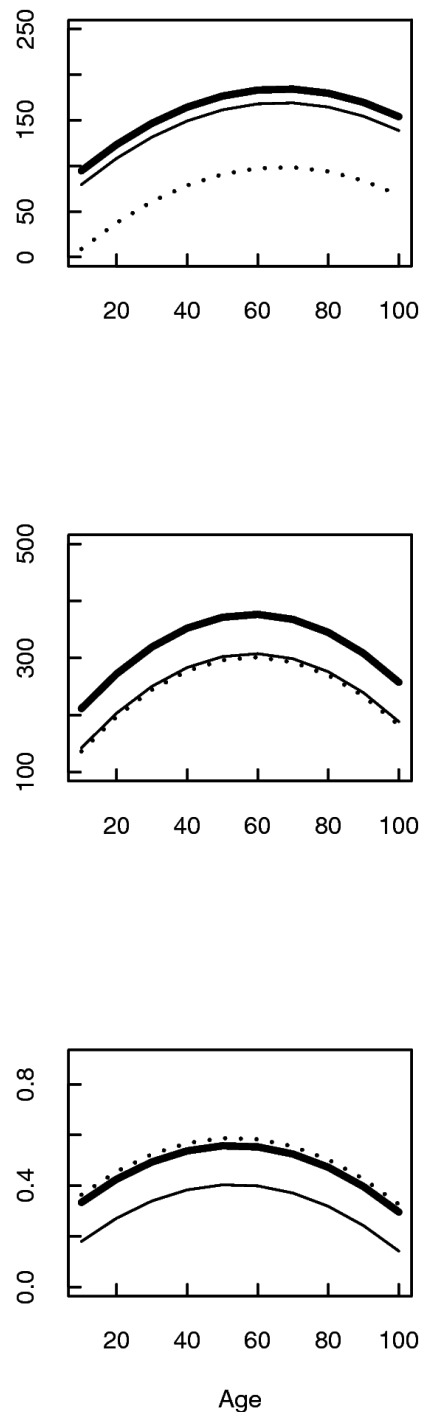


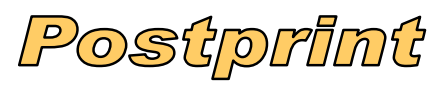

Version définitive du manuscrit publié dans / Final version of the manuscript published in : Journal of Evolutionary Biology, 2008, DOI: 10.1111/j.1420-9101.2008.01662.x

1 Figure 4

2

(a)

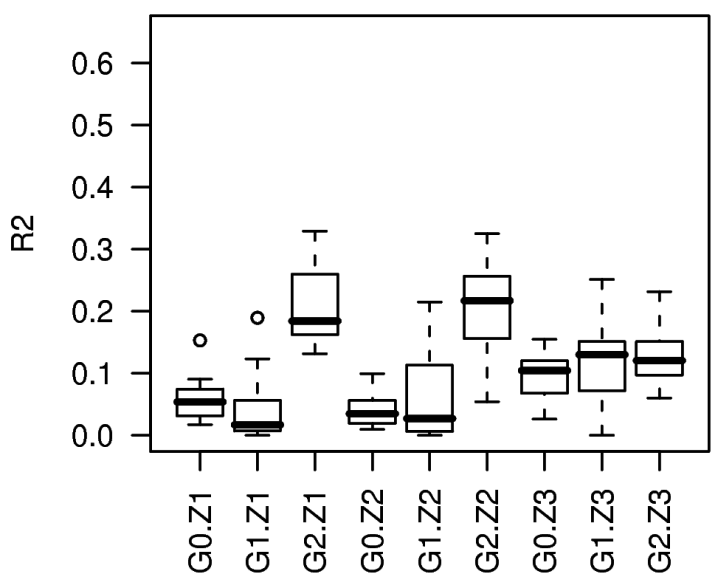

(b)

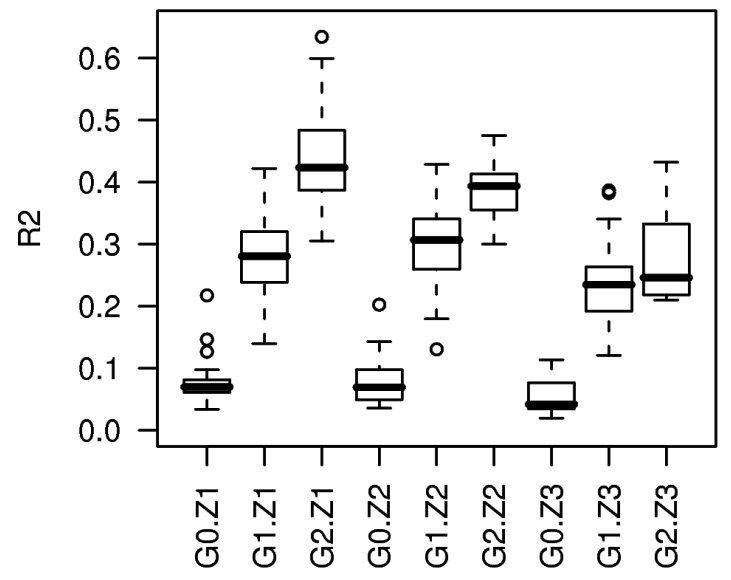




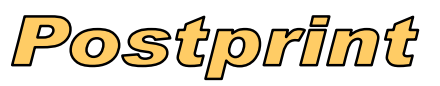

Version définitive du manuscrit publié dans / Final version of the manuscript

published in : Journal of Evolutionary Biology, 2008, DOI: 10.1111/j.1420-9101.2008.01662.x

1 - The only confounding effects found in our simulated cases were obtained when a spatial

2 structure within zones led to significant differences among zones or generations (seven

3 simulations with a significant Zone effect ; eleven with a significant $M J J A * Z o n e$ effect ;

4 three with significant Zone*Gen and $M J J A^{*} G e{ }^{*}$ Zone effects ; and four with significant

$5 \quad M J J A^{*}$ Gen effect in scenario \#4). The range simulated for the spatial effect was $50 \mathrm{~m}$, five

6 times smaller than the size of the experimental plots, and smaller ranges would probably

7 not result in such confounding. There was no significant spatial structure in the analysis of

8 the actual dataset anyway.

9 - Some effects were estimated with a low statistical power considering the data structure.

10 This is mainly the case for higher order interactions $\left(M J J A * Z o n e^{*}\right.$ Gen and MJJA*Zone to

11 a lesser extent) and for the variance-covariance parameters associated to the generations

$12 \mathrm{G} 2(\operatorname{Indiv}(G 2), M J J A * \operatorname{Indiv}(G 2))$ and $\mathrm{G} 1$ to a lesser extent.

13 - The residual variance parameters (Resid and $A R(1)$ parameters) were particularly well

14 estimated in all scenarios.

15 - The variance of the Individual effect was over estimated when the true value was low (e.g.

16265 to 996 instead of 100 for scenario 1); low values tend to be over-estimated for the

17 generation G2. This confirms the low value estimated from our data set.

18 - The variances of the random effects were well estimated (low bias) for the slope 19 parameter (MJJA*Indiv parameter) but slightly under-estimated in the scenario \#4 with a 20 spatial structure : $\sim 0.03$ instead of 0.04 .

21

22 
P○S\{

Version définitive du manuscrit publié dans / Final version of the manuscript published in : Journal of Evolutionary Biology, 2008, DOI: 10.1111/j.1420-9101.2008.01662.x

1 Table 1s: Description of the six scenarios used for simulating datasets. Scenario \#1

2 corresponds approximately to the results obtained with the actual dataset. In the description of

3 the other scenarios, the main changes with scenario \#1 are underlined.

4

Scenario \#1 variation among zones for growth and plasticity;

no variation among generations for growth, variation for plasticity;

quadratic effect of age;

random variation among years;

low inter-individual variance for growth and plasticity;

no spatial structure of the individual effect.

Scenario \#2 variation among zones for growth and plasticity;

no variation among generations for growth, variation for plasticity;

quadratic effect of age;

growth decreases with years;

low inter-individual variance for growth and plasticity;

no spatial structure of the individual effect.

Scenario \#3 variation among zones for growth and plasticity;

variation among generations for growth and plasticity;

quadratic effect of age;

growth decreases with years;

high inter-individual variance for growth and plasticity;

no spatial structure of the individual effect.

Scenario \#4 no variation among zones for growth and plasticity;

no variation among generations neither for growth nor for plasticity;

quadratic effect of age;

growth decreases with years;

very high inter-individual variance for growth and plasticity;

spatial structure of the individual effect both for growth and plasticity $(50 \mathrm{~m})$.

Scenario \#5 no variation among zones for growth and plasticity;

no variation among generations neither for growth nor for plasticity;

quadratic effect of age;

growth decreases and plasticity increases with years;

high inter-individual variance for growth and plasticity;

no spatial structure of the individual effect.

Scenario \#6 variation among zones for growth and plasticity;

no variation among generations neither for growth nor for plasticity;

quadratic effect of age;

growth decreases with years;

high inter-individual variance for growth and plasticity:

no spatial structure of the individual effect. 


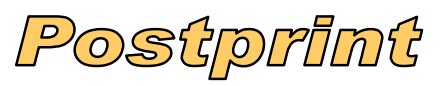

Version définitive du manuscrit publié dans / Final version of the manuscript published in : Journal of Evolutionary Biology, 2008, DOI: 10.1111/j.1420-9101.2008.01662.x

1 Table 2s: True values of the fixed effects and variance components for each scenario. See Fig

2 1s how the decrease in the Year effect was modelled in scenario \#2 to \#6.

Scenario \#1 $\quad$ Scenario \#2 $\quad$ Scenario \#3 $\quad$ Scenario \#4 Scenario \#5 Scenario \#6

Fixed effects

Intercept

150

150

150

150

150

150

Zone

$0 / 0 /-20$

$0 / 0 /-20$

$0 / 0 /-30$

$0 / 0 / 0$

$0 / 0 / 0$

$0 / 0 /-20$

Generation

$0 / 0 / 0$

$0 / 0 / 0$

$0 / 20 / 40$

$0 / 0 / 0$

$0 / 0 / 0$

$0 / 0 / 0$

Zone*Generation

Age

6

0

0

0

6

6

0

0

$A g e^{2}$

$-0.06$

$-0.06$

$-0.06$

6

6

MJJA

0.45

0.45

0.45

$-0.06$

$-0.06$

$-0.06$

Year

Random

Decrease $^{(1)}$

Decrease

0.45

Increase

0.45

MJJA*Zone

$0.25 / 0.15 / 0$

0.25/0.15/0

$0.25 / 0.15 / 0$

Decrease

Decrease

Decrease

$M J J A^{*}$ Gen

$-0.15 /-0.1 / 0$

$-0.15 /-0.1 / 0$

$-0.15 /-0.1 / 0$

$0 / 0 / 0$

$0 / 0 / 0$

$0.25 / 0.15 / 0$

MJJA*Zone*Gen

$$
\begin{array}{cc}
-0.2 /-0.2 / 0 & -0.2 /-0.2 / 0 \\
-0.1 /-0.1 / 0 & -0.1 /-0.1 / 0 \\
0 / 0 / 0 & 0 / 0 / 0
\end{array}
$$

$-0.2 /-0.2 / 0$

$0 / 0 / 0$

$0 / 0 / 0$

$0 / 0 / 0$

$-0.1 /-0.1 / 0$

0

0

0

MJJA*Age

0

0

$0 / 0 / 0$

$M J J A^{*} A g e^{2}$

0

0

0

0

0

0

0

0

0

Variance components

Indiv $(G 0)$

Indiv (G1)

$$
100
$$

$$
100
$$

2500

$$
4900
$$

2500

2500

Indiv (G2)

100

100

2500

4900

2500

2500

$M J J A * I n d i v(G 0)$

100

100

2500

4900

2500

2500

$M J J A * I n d i v(G 1)$

0.02

0.02

0.03

0.04

0.03

0.02

$M J J A{ }^{*}$ Indiv (G2)

0.01

0.01

0.03

0.04

0.03

0.02

$\operatorname{Cov}(\operatorname{Indiv}, P P)(G 0)$

0.01

0.01

0.03

0.04

0.03

0.02

$\operatorname{Cov}(\operatorname{Indiv}, P P)(G 1)$

0

0

0

0

0

$\operatorname{Cov}(\operatorname{Indiv}, P P)(G 2)$

0
0

0

0

$\operatorname{Resid}(G 0)$

27778

27778

27778

27778

27778

27778

0.8

0.8

0.8

0.8

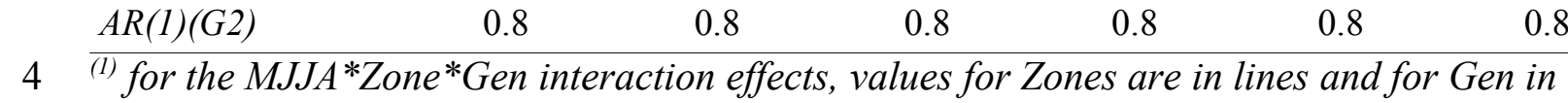

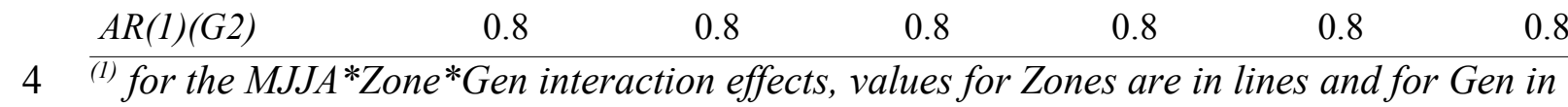

0

0

0

0

0

0

0

0

27778

27778

27778

27778

27778

27778

27778

27778

27778

27778

27778

27778

$A R(1)(G 0)$

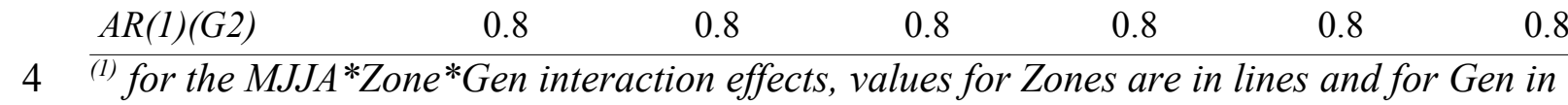

$0.8 \quad 0.8$

0.8

0.8

0.8

0.8

0.8

0.8

0.8

0.8

5 columns 


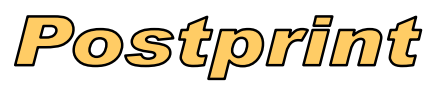

Version définitive du manuscrit publié dans / Final version of the manuscript published in : Journal of Evolutionary Biology, 2008, DOI: 10.1111/j.1420-9101.2008.01662.x

1 Table 3s: Number of convergent analyses and number of times each effect was found

2 significant out of 20 simulations for each scenario. The effects that were effectively present in

3 the simulated datasets appear in bold characters.

4

\begin{tabular}{lcccccc} 
& Scenario \#1 & Scenario \#2 & Scenario \#3 & Scenario \#4 & Scenario \#5 & Scenario \#6 \\
\hline Nb of simulations & 20 & 20 & 20 & 20 & 20 & 20 \\
Nb of successful & 12 & 19 & 20 & 18 & 17 & 18 \\
fits & & & & & & \\
(convergence) & & & & & &
\end{tabular}

Fixed effects

Zone
Generation
Zone*Generation
Age
Age ${ }^{2}$
MJJA
Year
MJJA*Zone
MJJA*Gen
MJJA*Zone*Gen
MJJA*Age
$M J J A^{*}{ }^{*}$ Age ${ }^{2}$

Random effects

\begin{tabular}{|c|c|c|}
\hline Indiv $(G 0)$ & 0 & 0 \\
\hline Indiv $(G 1)$ & 0 & 0 \\
\hline Indiv $(G 2)$ & 0 & 2 \\
\hline$M J J A * I n d i v(G 0)$ & 12 & 19 \\
\hline$M J J A^{*} \operatorname{Indiv}(G 1)$ & 8 & 12 \\
\hline$M J J A^{*} \operatorname{Indiv}(G 2)$ & 1 & 3 \\
\hline $\operatorname{Cov}($ Indiv,$P P)(G 0)$ & 1 & 1 \\
\hline $\operatorname{Cov}($ Indiv, $P P)(G 1)$ & 1 & 1 \\
\hline $\operatorname{Cov}(\operatorname{Indiv}, P P)(G 2)$ & 0 & 0 \\
\hline $\operatorname{Resid}(G 0)$ & 12 & 19 \\
\hline $\operatorname{Resid}(G 1)$ & 12 & 19 \\
\hline $\operatorname{Resid}(G 2)$ & 12 & 19 \\
\hline$A R(1)(G 0)$ & 12 & 19 \\
\hline$A R(1)(G 1)$ & 12 & 19 \\
\hline$A R(1)(G 2)$ & 12 & 19 \\
\hline
\end{tabular}

$18-17$

$17 \quad 18$

15

17

7

20

9

9

14

20

18

17

19

18

17

18

0

0

1

20

20

13

14

18

20

20

20

20

$$
1
$$$$
1
$$$$
11
$$

$$
1
$$$$
2
$$$$
0
$$

17

$\begin{array}{lll}18 & 17 & 18\end{array}$

$\begin{array}{lll}18 & 17 & 18\end{array}$

$\begin{array}{lll}18 & 17 & 18\end{array}$




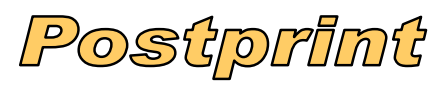

Version définitive du manuscrit publié dans / Final version of the manuscript published in : Journal of Evolutionary Biology, 2008, DOI: 10.1111/j.1420-9101.2008.01662.x

1 Table 4s: Mean estimated values of the variance components over 20 simulations for each

2 scenario.

3

\begin{tabular}{|c|c|c|c|c|c|c|}
\hline Var/Cov & Scenario \#1 & Scenario \#2 & Scenario \#3 & Scenario \#4 & Scenario \#5 & Scenario \#6 \\
\hline Indiv $(G 0)$ & 264.6 & 307.1 & 2831.5 & 3360.1 & 2161.7 & 2755.4 \\
\hline Indiv (G1) & 475.8 & 304.5 & 2493.1 & 4745.8 & 2225.8 & 2800.9 \\
\hline Indiv (G2) & 995.9 & 1372.3 & 3072.2 & 5039.3 & 2432.7 & 2133.3 \\
\hline$M J J A * \operatorname{Indiv}(G 0)$ & 0.017 & 0.015 & 0.029 & 0.029 & 0.027 & 0.017 \\
\hline$M J J A * I n d i v(G 1)$ & 0.011 & 0.010 & 0.032 & 0.031 & 0.028 & 0.016 \\
\hline$M J J A^{*} \operatorname{Indiv}(G 2)$ & 0.013 & 0.010 & 0.037 & 0.030 & 0.037 & 0.018 \\
\hline $\operatorname{Cov}(\operatorname{Indiv}, P P)(G 0)$ & 0.00 & -0.10 & -0.05 & 0.74 & 0.20 & 0.41 \\
\hline $\operatorname{Cov}(\operatorname{Indiv}, P P)(G 1)$ & -0.74 & 0.06 & -0.31 & 0.09 & 1.01 & -0.82 \\
\hline $\operatorname{Cov}(\operatorname{Indiv}, P P)(G 2)$ & -0.40 & -0.23 & -1.68 & -0.11 & 0.26 & 0.02 \\
\hline $\operatorname{Resid}(G 0)$ & 26855 & 26761 & 26459 & 27021 & 26795 & 26186 \\
\hline $\operatorname{Resid}(G 1)$ & 27408 & 27184 & 27748 & 27741 & 28041 & 27753 \\
\hline $\operatorname{Resid}(G 2)$ & 28166 & 27353 & 27276 & 27840 & 27881 & 28318 \\
\hline$A R(1)(G 0)$ & 0.79 & 0.79 & 0.79 & 0.80 & 0.79 & 0.79 \\
\hline$A R(1)(G 1)$ & 0.80 & 0.80 & 0.80 & 0.80 & 0.80 & 0.80 \\
\hline$A R(1)(G 2)$ & 0.80 & 0.80 & 0.80 & 0.80 & 0.80 & 0.81 \\
\hline
\end{tabular}


